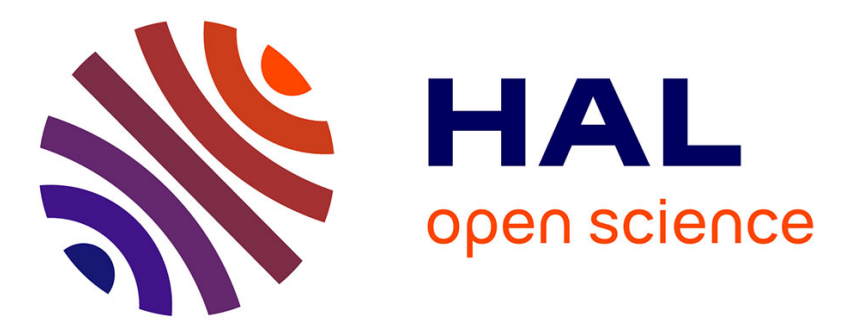

\title{
The Future of Digital Work: The Challenge of Inequality
}

\author{
Rajendra K. Bandi, Ranjini C. R., Stefan Klein, Shirin Madon, Eric Monteiro
}

\section{- To cite this version:}

Rajendra K. Bandi, Ranjini C. R., Stefan Klein, Shirin Madon, Eric Monteiro. The Future of Digital Work: The Challenge of Inequality: IFIP WG 8.2, 9.1, 9.4 Joint Working Conference, IFIPJWC 2020, Hyderabad, India, December 10-11, 2020, Proceedings. Springer International Publishing, AICT-601, 2020, IFIP Advances in Information and Communication Technology, 978-3-030-646967. 10.1007/978-3-030-64697-4 . hal-03450751

\section{HAL Id: hal-03450751 \\ https://hal.inria.fr/hal-03450751}

Submitted on 26 Nov 2021

HAL is a multi-disciplinary open access archive for the deposit and dissemination of scientific research documents, whether they are published or not. The documents may come from teaching and research institutions in France or abroad, or from public or private research centers.
L'archive ouverte pluridisciplinaire HAL, est destinée au dépôt et à la diffusion de documents scientifiques de niveau recherche, publiés ou non, émanant des établissements d'enseignement et de recherche français ou étrangers, des laboratoires publics ou privés. 


\section{IFIP Advances in Information and Communication Technology}

\section{Editor-in-Chief}

Kai Rannenberg, Goethe University Frankfurt, Germany

\section{Editorial Board Members}

TC 1 - Foundations of Computer Science

Luís Soares Barbosa (D), University of Minho, Braga, Portugal

TC 2 - Software: Theory and Practice

Michael Goedicke, University of Duisburg-Essen, Germany

TC 3 - Education

Arthur Tatnall ${ }^{D}$, Victoria University, Melbourne, Australia

TC 5 - Information Technology Applications

Erich J. Neuhold, University of Vienna, Austria

TC 6 - Communication Systems

Burkhard Stiller, University of Zurich, Zürich, Switzerland

TC 7 - System Modeling and Optimization

Fredi Tröltzsch, TU Berlin, Germany

TC 8 - Information Systems

Jan Pries-Heje, Roskilde University, Denmark

TC 9 - ICT and Society

David Kreps (iD, University of Salford, Greater Manchester, UK

TC 10 - Computer Systems Technology

Ricardo Reis(D, Federal University of Rio Grande do Sul, Porto Alegre, Brazil

TC 11 - Security and Privacy Protection in Information Processing Systems

Steven Furnell $\mathbb{D}$, Plymouth University, UK

TC 12 - Artificial Intelligence

Eunika Mercier-Laurent ${ }^{\mathbb{D}}$, University of Reims Champagne-Ardenne, Reims, France

TC 13 - Human-Computer Interaction

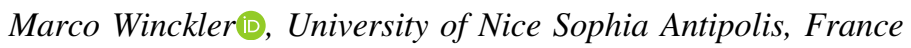

TC 14 - Entertainment Computing

Rainer Malaka, University of Bremen, Germany 


\section{IFIP - The International Federation for Information Processing}

IFIP was founded in 1960 under the auspices of UNESCO, following the first World Computer Congress held in Paris the previous year. A federation for societies working in information processing, IFIP's aim is two-fold: to support information processing in the countries of its members and to encourage technology transfer to developing nations. As its mission statement clearly states:

IFIP is the global non-profit federation of societies of ICT professionals that aims at achieving a worldwide professional and socially responsible development and application of information and communication technologies.

IFIP is a non-profit-making organization, run almost solely by 2500 volunteers. It operates through a number of technical committees and working groups, which organize events and publications. IFIP's events range from large international open conferences to working conferences and local seminars.

The flagship event is the IFIP World Computer Congress, at which both invited and contributed papers are presented. Contributed papers are rigorously refereed and the rejection rate is high.

As with the Congress, participation in the open conferences is open to all and papers may be invited or submitted. Again, submitted papers are stringently refereed.

The working conferences are structured differently. They are usually run by a working group and attendance is generally smaller and occasionally by invitation only. Their purpose is to create an atmosphere conducive to innovation and development. Refereeing is also rigorous and papers are subjected to extensive group discussion.

Publications arising from IFIP events vary. The papers presented at the IFIP World Computer Congress and at open conferences are published as conference proceedings, while the results of the working conferences are often published as collections of selected and edited papers.

IFIP distinguishes three types of institutional membership: Country Representative Members, Members at Large, and Associate Members. The type of organization that can apply for membership is a wide variety and includes national or international societies of individual computer scientists/ICT professionals, associations or federations of such societies, government institutions/government related organizations, national or international research institutes or consortia, universities, academies of sciences, companies, national or international associations or federations of companies.

More information about this series at http://www.springer.com/series/6102 
Rajendra K. Bandi - Ranjini C. R. •

Stefan Klein - Shirin Madon .

Eric Monteiro (Eds.)

\section{The Future of Digital Work: The Challenge of Inequality}

IFIP WG 8.2, 9.1, 9.4 Joint Working Conference, IFIPJWC 2020 Hyderabad, India, December 10-11, 2020

Proceedings 


\title{
Editors
}

Rajendra K. Bandi

Indian Institute of Management Bangalore

Bangalore, India

\section{Stefan Klein}

University of Münster

Münster, Germany

\section{Eric Monteiro}

Norwegian University of Science

and Technology

Trondheim, Norway
Ranjini C. R.

Ramalingaswami Centre on Equity and Social Determinants of Health Bangalore, India

Shirin Madon

London School of Economics

and Political Science

London, UK

\author{
ISSN 1868-4238 ISSN 1868-422X (electronic) \\ IFIP Advances in Information and Communication Technology \\ ISBN 978-3-030-64696-7 ISBN 978-3-030-64697-4 (eBook) \\ https://doi.org/10.1007/978-3-030-64697-4
}

(C) IFIP International Federation for Information Processing 2020

This work is subject to copyright. All rights are reserved by the Publisher, whether the whole or part of the material is concerned, specifically the rights of translation, reprinting, reuse of illustrations, recitation, broadcasting, reproduction on microfilms or in any other physical way, and transmission or information storage and retrieval, electronic adaptation, computer software, or by similar or dissimilar methodology now known or hereafter developed.

The use of general descriptive names, registered names, trademarks, service marks, etc. in this publication does not imply, even in the absence of a specific statement, that such names are exempt from the relevant protective laws and regulations and therefore free for general use.

The publisher, the authors and the editors are safe to assume that the advice and information in this book are believed to be true and accurate at the date of publication. Neither the publisher nor the authors or the editors give a warranty, expressed or implied, with respect to the material contained herein or for any errors or omissions that may have been made. The publisher remains neutral with regard to jurisdictional claims in published maps and institutional affiliations.

This Springer imprint is published by the registered company Springer Nature Switzerland AG The registered company address is: Gewerbestrasse 11, 6330 Cham, Switzerland 


\section{Preface}

The papers in this volume constitute the proceedings of a joint working conference organized by the IFIP Working Groups 8.2, 9.1, and 9.4. The conference, entitled "The future of digital work: the challenge of inequality," was planned to take place during December 9-10, 2020, in Hyderabad, India. Due to the COVID-19 pandemic the conference was held virtually.

The call for papers resulted in a total of 29 submissions. Of these, 22 full papers were finally selected for presentation at the working conference. The submissions were selected through a blind-review process involving two reviewers and the editors. Authors of submissions that were selected for the next round were requested to revise their contributions in accordance with the reviewers' and the editors' recommendations. The revised submissions were then reviewed for publication in this volume. An introductory paper by the editors provides a thematic overview of these papers.

The papers published in this volume are complemented by contributions from the two keynote speakers at the conference: Renana Jhabvala and Michael Barrett.

Renana Jhabvala, Chairperson SEWA Bharat and Grih Rin Ltd, is an Indian social worker, who has been active for decades in organizing women in the informal economy into trade unions, co-operatives, and financial institutions in India, and has been extensively involved in policy issues relating to poor women and the informal economy.

Michael Barrett, Professor of Information Systems and Innovation Studies at the Cambridge Judge Business School, UK, has a long track record of engaging with social aspects of digital technologies, also with a view to the global south.

The editors would like to take this opportunity to thank all the contributors to this volume. We are very grateful to all the members of the Program Committee who participated in the review process. We give special thanks to Arunima S. Mukherjee and Divya Sharma for all their hard work on the conference organization. We would also like to recognize Eija Karsten, who has initiated the joint conference, working closely with the conference chairs Rajesh Chandwani, Shirin Madon, and Jungwoo Lee, who also took responsibility for the RIP stream, and Miriam Costales and her colleagues at Springer, who helped in producing these proceedings.

The local host organizations are the Indian Institute of Management, Ahmedabad, India, and Society for Health Information Systems Program - HISP India, New Delhi, India.

October 2020

Rajendra K. Bandi

Ranjini C. R.

Stefan Klein

Shirin Madon

Eric Monteiro 


\section{Organization}

\section{Program Chairs}

Rajendra K. Bandi

Ranjini C. R.

Stefan Klein

Shirin Madon

Eric Monteiro

\section{Organizing Chairs}

Arunima S. Mukherjee

\section{Program Committee}

\author{
Steve Sawyer \\ Brian Nicholson \\ Silvia Masiero \\ Neil Pollock \\ Sundeep Sahay \\ Carla Bonina \\ Suzana Brown \\ Richard Heeks \\ Fareesa Malik \\ Nathalie Mitev \\ Abayomi Baiyere \\ Matti Rossi \\ Séamas Kelly \\ Ella Hafermalz \\ Anastasia Sergeeva \\ Panos Constantinides \\ Chrisanthi Avgerou \\ Jan Ljungberg \\ Eivor Oborn-Barrett \\ Yingqin Zheng \\ Daniel Fuerstenau \\ Jonny Holmstrom
}

Indian Institute of Management Bangalore, India Ramalingaswami Centre on Equity and Social

Determinants of Health, India

University of Münster, Germany

London School of Economics and Political Science, UK

Norwegian University of Science and Technology,

Norway

$$
\text { University of Oslo, Norway }
$$

Syracuse University, USA
The University of Manchester, UK
Loughborough University, UK
The University of Edinburgh, UK
University of Oslo, Norway
Surrey Business School, UK
SUNY Korea, South Korea
The University of Manchester, UK
NUST Business School, Pakistan
Paris Dauphine University, France
Copenhagen Business School, Denmark
Aalto University, Finland
University College Dublin, Ireland
Vrije Universiteit Amsterdam, The Netherlands
Vrije Universiteit Amsterdam, The Netherlands
Alliance Manchester Business School, UK
London School of Economics, UK
Gothenburg University, Sweden
University of Warwick, UK
Royal Holloway, University of London, UK
Freie Universität Berlin, Germany
Umeå University, Sweden


Matthew Jones

Ineke Buskens

M. Lynne Markus

Petter Nielsen
University of Cambridge, UK

Research For the Future CC, Macau

Bentley University, USA

University of Oslo, Norway 


\section{Contents}

\section{Introduction}

The Future of Digital Work: The Challenge of Inequality. . . . . . . . . . . . 3

Rajendra K. Bandi, Stefan Klein, Shirin Madon, Eric Monteiro, and C. R. Ranjini

\section{Keynotes}

Overcoming Gender Inequality in the Digital World . . . . . . . . . . . . . 13 Renana Jhabvala

Riskscapes and the Scaling of Digital Innovation: Trajectory Dynamics of Mobile Payments in Times of Crisis . . . . . . . . . . . . . .

Michael Barrett

\section{Innovation and Entrepreneurship}

Review of the Nexus Between Trust and Respect in Entrepreneurs'

Information-Seeking Behaviour. . . . . . . . . . . . . .

Thao Orrensalo and Shahrokh Nikou

Entrepreneurs and ICT Technology in the Dzaleka Refugee Camp . . . . . . 38 Suzana Brown and Patience Desire

Perceptions of Rwanda's Research Environment in the Context of Digitalization: Reflections on Deficit Discourses . . . . . . . . . . . .

Pamela Abbott and Andrew Cox

\section{The Social Significance of Digital Platforms}

Surviving the Gig Economy in the Global South: How Cape Town

Domestic Workers Cope . . . . . . . . . . . . . . . . . . . . . .

Boitumelo Lesala Khethisa, Pitso Tsibolane, and Jean-Paul Van Belle

Social Enablers and Constraints Related to the Publication and Use of Open

Government Data in a Developing Country . . . . . . . . . . . . . . . . . .

Hubeidatu Nuhu, Jean-Paul Van Belle, and Marita Turpin

Attitudes Toward and Experiences of Digital Labour in South Africa . . . . . . 
Are Ride-Sharing Platforms Good for Indian Drivers? An Investigation of Taxi and Auto-Rickshaw Drivers in Delhi . . . . . . . . . . . . . . .

Anna Fleitoukh and Kentaro Toyama

Spatiotemporal (In)justice in Digital Platforms: An Analysis

of Food-Delivery Platforms in South India . . . . . . . . . . . .

Shyam Krishna

Understanding Platform Ecosystems for Development: Enabling Innovation

in Digital Global Public Goods Software Platforms . . . . . . . . . . . . . .

Scott Russpatrick

\section{Transforming Healthcare}

Power, Technology and Empowerment: A Case Study of Community

Health Workers in India. . . . . . . . . . . . . . . . . . . . . . . .

Priyanka Pandey and Yingqin Zheng

Practical Affordance: EMR Use Within Outpatient Consulting on Women's

Health . . . . . . . . . . . . . . . . . . . . . . . . . . . . . .

Ayushi Tandon

Sustainability Qualifiers of Health Management Information Systems

Implementation: Case Study of DHIS2 in India. . . . . . . . . . . . . . . .

Jyotsna Sahay, Sundeep Sahay, and Arunima Sehgal Mukherjee

Patients' Trust in Public Health System Mediated by Hospital Information

Systems in Context of LMIC . . . . . . . . . . . . . . . . . . . . . . . . .

Harleen Kaur, Sundeep Sahay, and Arunima Mukherjee

Building Agility in Health Information Systems to Respond to the

COVID-19 Pandemic: The Sri Lankan Experience . . . . . . . . . . . . . . . . .

Pamod Amarakoon, Jørn Braa, Sundeep Sahay, Pandula Siribaddana, and Roshan Hewapathirana

Rapid Systems Response to COVID-19: Standards Disseminated as Digital Health Packages . . . . . . . . . . . . . . . . . . . . . .

Olav Poppe, Zeferino Saugene, Edem Kossi, Johan Ivar Sabø, and Jørn Braa

Designing for Scale: Strengthening Surveillance of Antimicrobial Resistance in Low Resource Settings. . . . . . . . . . . . . . . . . . . . . . . .

Sundeep Sahay, Gitika Arora, Yogita Thakral, Ernst Kristian Rødland, and Arunima Sehgal Mukherjee 


\section{The Dark Side of Digitalisation}

Digital Technology for Unmasking Labour Exploitation in Supply Chains . . . Hannah Thinyane and Francisca Sassetti

In Technology We Trust? Human Skills \& Intermediaries in Digital

Retail Banking . . . . . . . . . . . . . . . . . . . .

Soumyo Das and Bidisha Chaudhuri

The Five-Dimensional Space of the Futures of Work: A View to 2030 . . . . Erran Carmel and Steve Sawyer

Humanoid Social Robots and the Reconfiguration of Customer Service . . . . . Gabriella Volpe, Matthias Schulte-Althoff, David Dillmann, Emmanuelle Maurer, Yannic Niedenzu, Philipp Schließer, and Daniel Fürstenau

The Role of Social Capital in Mediating ICT-Enabled Peace Building Efforts: A Case Study from Kenya . . . . . . . . . . . . . . . . . . . . . . . .

Festus Mukoya and Arunima Sehgal Mukherjee

What Will the Future of Work Look like for IS Professionals?

The Picture of Portugal . . . . . . . . . . . . . . . . . . . .

Anabela Mesquita, Ana Paula Camarinha, Filomena Castro Lopes, and Pedro Malta 